\title{
Marine sediments as a source of atmospheric methane
}

\author{
RAY E. CRANSTON
}

1

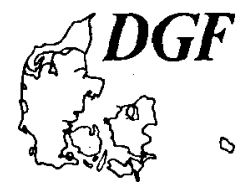

\author{
Cranston, R. E.: Marine sediments as a source of atmossperic methane. Bulletin of the \\ Geolog-ical Society of Denmark, Vol. 41, pp. 101-109. Copenhagen, 1994-03-30. \\ https://doi.org/10.37570/bgsd-1995-41-11
}

\begin{abstract}
Methane sources and sinks have been evaluated at 10 sites off the east coasts of Canada and Russia. More than $99 \%$ of the diffusive methane flux from marine sediments appears to be consumed by microbial oxidation when dissolved sulfate is present. At 3 sites, methane bubble vents were found. Two of the vents, located in the Okhotsk Sea, appear to result from gas being released along faults. The third plume site was located in a shallow harbour where a large amount of organic carbon is deposited in shallow water. The global diffusive and advective (bubbles) release of methane to the atmosphere from marine sediments is estimated to fall into the range of $1-10 \mathrm{TgC} \mathrm{a}^{-1}\left(1 \mathrm{Tg}=10^{12} \mathrm{~g}\right)$.

Researchers have speculated that marine gas hydrate deposits hold vast quantitites of methane that may melt and be released as a result of global warming. A warmer atmosphere could directly heat the ocean and/or change ocean current systems, which could bring warmer water to some areas. Hydrate samples were recovered from two sites in the Okhotsk Sea. These deposits, in 700 to $800 \mathrm{~m}$ of water, would require water temperatures to increase by $8^{\circ} \mathrm{C}$ in order to melt the hydrate. Quantitative estimates of hydrate reservoirs near the minimum pressure stability zone are needed to remove the uncertainty whether this will be a significant positivefeedback loop for global warming.
\end{abstract}

Ray. E. Cranston, Geological Survey of Canada, Bedford Institute of Oceanography, Box 1006, Dartmouth, Nova Scotia, Canada B2Y 4A2. September 25th, 1992.

\section{Introduction}

Methane is the most abundant organic carbon compound in the atmosphere and is much more effective as a greenhouse gas in capturing radiation than carbon dioxide (Houghton et al., 1990). Methane accounts for about 15\% of the anthropogenic greenhouse effect and is accumulating in the atmosphere at a rate of about $0.8 \%$ per year, compared to $0.5 \%$ per year for $\mathrm{CO}_{2}$ (Houghton et al., 1990). On the order of $500 \mathrm{TgC}\left(1 \mathrm{Tg}=10^{12} \mathrm{~g}\right)$ as methane enters the atmosphere each year (Cicerone \& Oremland, 1988). Man's activity such as agriculture (animal digestion, rice paddies), mining, petroleum production, biomass burning and land fill sites provide approximately half of the input while natural sources such as wet lands, termites, biomass burning, lakes, oceans and gas hydrates release the other half (Houghton et al., 1990). Atmospheric methane is oxidized by hydroxyl radicals, accounting for the destruction of $\sim 400 \mathrm{TgC}$ each year (Cicerone \& Oremland, 1988).

\section{Marine Methane}

Methane release estimates from oceans and marine sediments to the atmosphere are on the order of 1 to $10 \mathrm{TgC}$ $\mathrm{a}^{-1}$ (Cicerone \& Oremland, 1988; Lambert \& Schmidt, 1992), while the potential release from gas hydrate de- posits (ice-like mixtures of methane and water) has been estimated to be as much as $100 \mathrm{TgC} \mathrm{a}{ }^{-1}$ (Kvenvolden, 1988; Nisbet, 1989). The predominant source of methane in the marine environment is due to anaerobic bacteria using organic carbon or acetate in the sediment column as an energy source (Martens \& Val Klump, 1984). Methane-rich sediments are often found in coastal inlets and basins where high biological productivity provides a high carbon flux to the sediment column, resulting in anoxic sediments and methane formation. Temperature, organic matter quality and quantity, and the age of the deposit have an effect on bacterial methane production. Carbon and hydrogen isoptope variations in methane are often used to identify the mechanism of formation. These topics are beyond the scope of this discussions, however details about microbial methane production are available in Schoell (1988) and Whiticar et al. (1986).

Methane is also present in marine sediments as a result of petroleum formation processes (MacDonald, 1983). Because these processes require temperatures and pressures found at hundreds to thousands of metres in the sediment column, these 'thermogenic' methane deposits are isolated from the oceans and atmosphere. A third source of methane in marine sediments is associated with primordial gas releases at seafloor spreading ridges and sub-sea volcanic sites (Welham \& Craig, 1979). While quantiative release estimates are not available, oxidation 


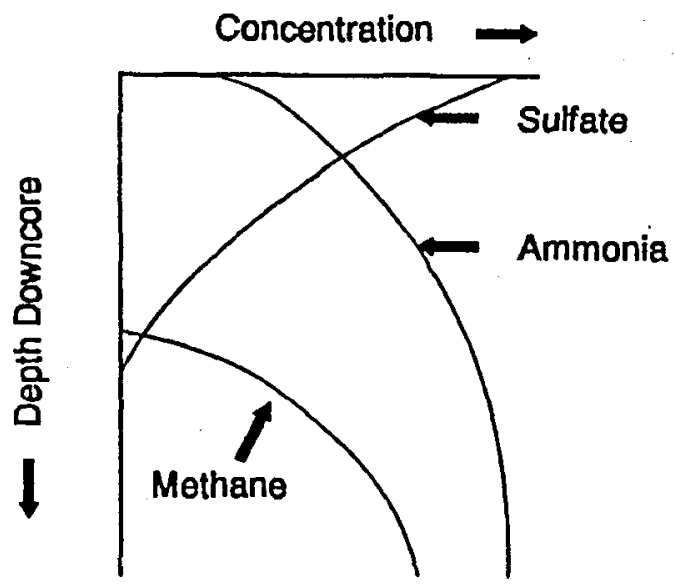

Fig. 1. Generalized concentration profiles for methane, sulfate and ammonia in pore water.

near deep sea hydrothermal vents limits the amount of methane released to the sea (de Angelis, 1989) and to the atmosphere.

Local methane anomalies in sea water have been found adjacent to rivers (Scranton \& McShane, 1991), associated with highly productive biological areas (Martens \& Val Klump, 1984), and as a result of methane seeps from seabed sediments (Cynar \& Yayanos, 1992; Dando et al., 1991; Martens et al., 1991; Matson, 1986). A quantitative estimate of the amount of methane in marine sediments and the amount being released to the atmosphere has not been made due to a lack of research and to inadequate sampling methods. Almost all marine sediment samples are collected with unpressurized methods. As the samples are returned to sea level, the drop in pressure allows dissolved methane to enter the gas phase. An unknown amount of methane escapes before the samples can be sealed in containers. Other evidence of methane in the sediment column is even less quantitative. A variety of sea floor features are often associated with gas deposits and gas venting, e.g. pockmarks and mud volcanoes, bacterial mats and enhanced biological activity, (Fader, 1991; Hovland \& Judd, 1988); seismic record masking and bottom simulating relflectors (Anderson \& Bryant, 1990; Miller et al., 1991), however there is generally no gas analyses done to verify that methane is responsible for the features.

The main purpose of this paper is to estimate how much methane is released from marine sediments to the atmosphere, based on recent studies carried out on the east coasts of Canada and Russia. In addition, speculation about future potential releases due to global warming and anthropogenic activity will be presented.

\section{Sampling and analytical methods}

Table 1 contains information about a number of expeditions since 1988 that have studied the occurrence and release of methane from marine sediments. Sediment cores were collected by box, gravity and piston cores and subsampled at 5 to $50 \mathrm{~cm}$ intervals prior to centrifuging or squeezing the sediment to recover pore water. In some cases, a $250 \mathrm{ml}$ portion of wet sediment was sealed in 500 $\mathrm{ml}$ containers and later analyzed by gas chromatography to measure methane in the headspace gas. A number of coring transects were done along the east coast of Canada in water depths of 350 to $600 \mathrm{~m}$ to search for methane hydrate deposits near the sediment-water interface that could be vulnerable to melting if global warming affects the temperature of the upper ocean.

As soon as most sediment cores were brought onboard, a $5 \mathrm{~L}$ plastic bag was immediately sealed around the exposed end of the core. A constant flow gas pump (Industrial Scientific SP200) transfered gas from the plastic bag to an Industrial Scientific HMX271 gas detector. Methane and hydrogen sulfide concentrations were recorded. The detection limit was 500 ppmv for methane and 1 ppmv hydrogen sulfide.

Pore water samples were analyzed for sulfate using a turbidimetric method. A $50 \mu \mathrm{L}$ portion of pore water was placed in a $5 \mathrm{ml}$ cuvette. A $50 \mu \mathrm{L}$ portion of $300 \mathrm{mM}$ barium chloride was immediately added to precipitate barium sulfate, then $4 \mathrm{~mL}$ of de-ionized water was added. The turbidity of the solution was measured using a Milton Roy Spectronic Mini20 fitted with a turbidity meter. A standard calibration curve was obtained using dilutions of international standard sea water. Analytical precision and accuracy was found to be $\pm 2 \mathrm{mM}$.

Ammonia determinations were carried out on $100 \mu \mathrm{L}$ portions of pore water using the colorimetric method described by Solarzano (1969). Precision and accuracy variations account for relative errors on the order of \pm $10 \%$.

After pore water was recovered, the residual sediment was freeze dried and later analyzed for organic carbon using a Leco WR-112 carbon analyzer. Precision and accuracy estimates are $\pm 5 \%$ of the amount present.

\section{Results}

\section{Methane Measurements and Redox Conditions}

As organic matter is oxidized by anaerobic bacteria, ammonia is released and sulfate is consumed in amounts proportional to the organic carbon burial flux (Canfield, 1989; Cranston, 1991a; Henrichs \& Reeburgh, 1987). Significant methane concentrations are found only where dissolved sulfate is depleted (Fig. 1) (e.g. Alperin \& Reeburgh, 1985; Devol, 1983; Iversen \& Jørgensen, 1985). The concentrations gradients for sulfate and ammonia are included in table 2, summarizing results from $>$ 
Table 1. Study Area Locations.

\begin{tabular}{llll}
\hline Area & Latitude & Longitude & Reference \\
\hline $\begin{array}{l}\text { Aquaculture site, New Brunswick, Canada } \\
\text { Halifax Harbour, Nova Scotia, Canada }\end{array}$ & $\begin{array}{l}45^{\circ} 03^{\prime} \mathrm{N} \\
44^{\circ} 38^{\prime} \mathrm{N}\end{array}$ & $\begin{array}{l}66^{\circ} 50^{\prime} \mathrm{W} \\
63^{\circ} 34^{\prime} \mathrm{W}\end{array}$ & $\begin{array}{l}\text { Unpublished } \\
\text { Fitzgerald et al., 1991; } \\
\text { Buckley et al., 1991; } \\
\text { LeBlanc et al., 1991 }\end{array}$ \\
$\begin{array}{l} \\
\text { Eastern Canadian Continental Margin }\end{array}$ & & \\
$91020-40,91020-29$ & & & \\
$91020-79$ & $44^{\circ} 41^{\prime} \mathrm{N}$ & $55^{\circ} 34^{\prime} \mathrm{W}$ & Unpubl. cruise report \\
$88010-18,88010-28$ & $47^{\circ} 34^{\prime} \mathrm{N}$ & $46^{\circ} 35^{\prime} \mathrm{W}$ & Unpubl. cruise report \\
$88010-02,88010-05$ & $43^{\circ} \mathrm{N}$ & $62^{\circ} \mathrm{W}$ & Buckley, 1991 \\
Okhotsk Sea & $44^{\circ} \mathrm{N}$ & $63^{\circ} \mathrm{W}$ & Buckley, 1991 \\
910133,910118 & $50^{\circ} 31^{\prime} \mathrm{N}$ & $155^{\circ} 18^{\prime} \mathrm{E}$ & Cranston, 1991b \\
910252 to 910270 & $53^{\circ} 30^{\prime} \mathrm{N}$ & $144^{\circ} 30^{\prime} \mathrm{E}$ & Cranston, 1991b \\
Japan Sea & $44^{\circ} 10^{\prime} \mathrm{N}$ & $136^{\circ} 30^{\prime} \mathrm{E}$ & Cranston, 1991b \\
Passamaquady Bay, New Brunswick, Canada & $45^{\circ} 02^{\prime} \mathrm{N}$ & $66^{\circ} 52^{\prime} \mathrm{W}$ & Unpubl. cruise report \\
Toney River, Nova Scotia, Canada & $45^{\circ} 50^{\prime} \mathrm{N}$ & $63^{\circ} 40^{\prime} \mathrm{W}$ & Unpublished observ. \\
\hline
\end{tabular}

1100 pore water samples from cores collected at the sites listed in table 1. Semi-quantitative methane results are also included. Average organic carbon concentrations and estimates of present day sedimentation rates are included.

Methane was measured at 10 of the 12 coastal sites listed in table 1. In Halifax Harbour where sedimentation rates are 200 to $600 \mathrm{~cm} \mathrm{Ka}^{-1}$ and organic carbon concentrations vary from 1 to $7 \%$, sulfate was present in the upper 0.5 to $1 \mathrm{~m}$ of the sediment column, below which methane was generally found. Seismic survey records show areas where methane gas bubbles exist in the sediment, as they severely degrade the seismic records. Along the continental margin of Eastern Canada where sedimentation rates and organic carbon contents are lower, methane was found in the sediment column at depths of 3 to $10 \mathrm{~m}$.

Gas venting from the sea floor was observed during two field programs. In the Okhotsk Sea off the east coast
Fig. 2. Concentrations gradients for ammonia vs sulfate.

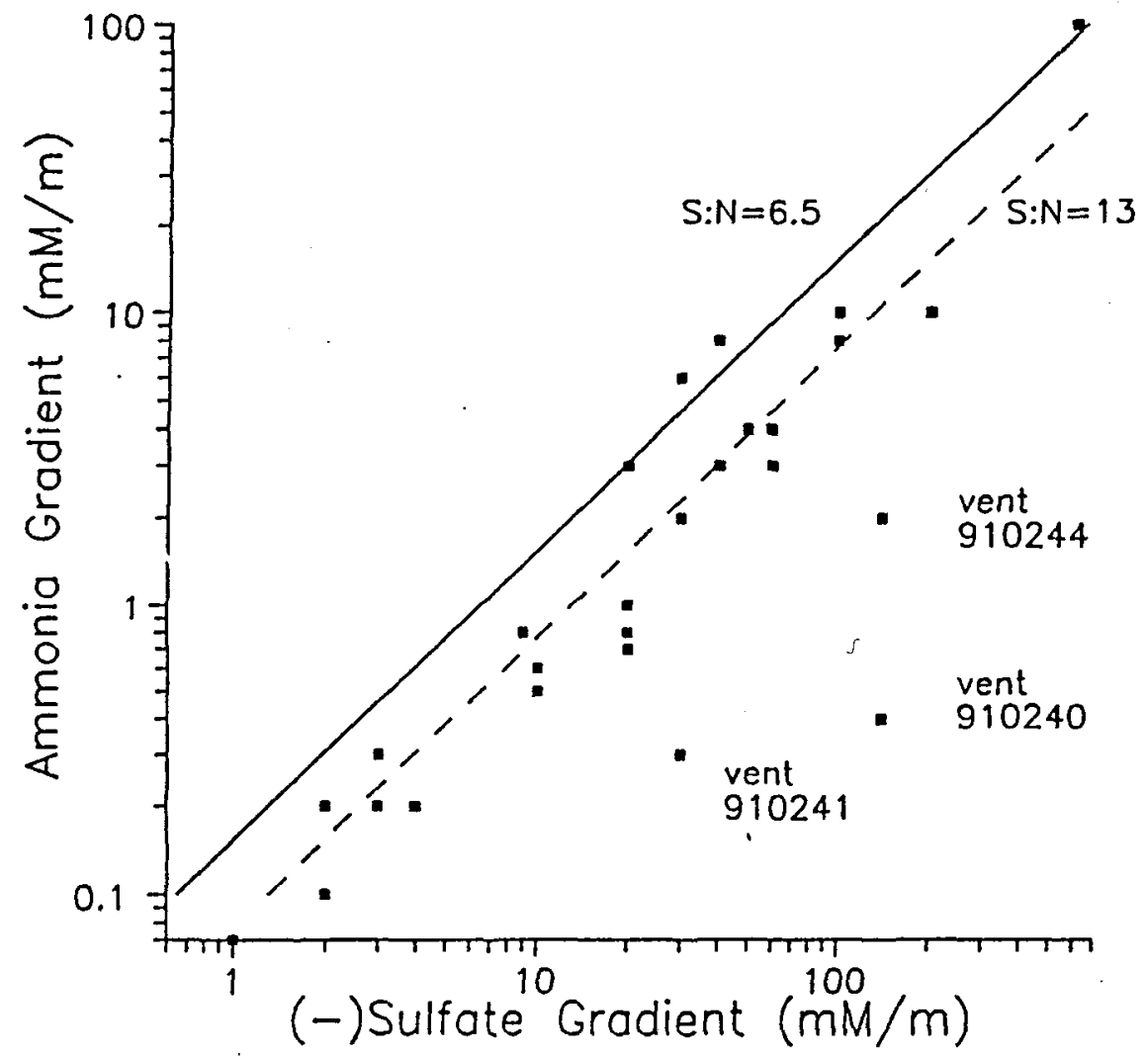


Table 2. Geochemical Results.

\begin{tabular}{|c|c|c|c|c|c|c|}
\hline Location & $\begin{array}{l}\text { Water } \\
\text { Depth } \\
\text { (m) }\end{array}$ & $\begin{array}{l}\text { Methane } \\
\text { (\% vol) }\end{array}$ & $\begin{array}{l}\text { Sulfate } \\
\text { Gradient } \\
\left(\mathrm{mM} \mathrm{m}^{-1}\right)\end{array}$ & $\begin{array}{l}\text { Ammonia } \\
\text { Gradient } \\
\left(\mathrm{mM} \mathrm{m}^{-1}\right)\end{array}$ & $\begin{array}{l}\text { Organic } \\
\text { Carbon } \\
(\%)\end{array}$ & $\begin{array}{l}\text { Sed. } \\
\text { Rate } \\
\left(\mathrm{cm} \mathrm{Ka}^{-1}\right)\end{array}$ \\
\hline Aquaculture & 15 & $\mathrm{dl}$ & 600 & 100 & 10 & 5000 \\
\hline \multicolumn{6}{|c|}{ Halifax Harbour } & 300 \\
\hline $90010-18$ & 67 & na & 100 & 8 & 7 & 200 \\
\hline Creed 33 & 10 & 2 & 100 & 8 & 5 & 300 \\
\hline Creed 35 & 10 & na & 100 & 10 & 6 & $200^{c}$ \\
\hline Creed 32 & 18 & 2 & 60 & 3 & 6 & 600 \\
\hline $90010-14$ & 18 & na & 40 & 3 & 1 & $300^{c}$ \\
\hline 89039-02 & 20 & 3 & 60 & 4 & 2 & $200^{\mathrm{c}}$ \\
\hline $89009-24$ & 11 & na & 50 & 4 & 4 & 200 \\
\hline 89009-01 & 62 & na & 40 & 8 & 4 & 300 \\
\hline $89009-16$ & 24 & na & 30 & 6 & 4 & 400 \\
\hline 89009-03 & 11 & na & 20 & 3 & 5 & 200 \\
\hline \multicolumn{7}{|c|}{ E. Canadian Margin } \\
\hline $91020-40$ & 1060 & 6 & 30 & 2 & .7 & $300^{c}$ \\
\hline $91020-29$ & 1330 & 0.6 & 20 & 1 & .7 & $200^{c}$ \\
\hline $91020-79$ & 1140 & .01 & 4 & .2 & .4 & 30 \\
\hline $88010-18$ & 1342 & na & 3 & .2 & .7 & $40^{\mathrm{c}}$ \\
\hline $88010-05$ & 240 & na & 3 & .2 & .9 & 40 \\
\hline $88010-02$ & 201 & na & 2 & .2 & .5 & 20 \\
\hline $88010-28$ & 3825 & na & 1 & .07 & .4 & $20^{c}$ \\
\hline \multicolumn{7}{|l|}{ Okhotsk Sea } \\
\hline 910133 & 798 & 4 & 20 & .8 & .6 & $100^{c}$ \\
\hline 910118 & 804 & .01 & 10 & .6 & .6 & $100^{c}$ \\
\hline 910252 & 642 & .01 & 20 & .7 & 1 & $50^{c}$ \\
\hline 910253 & 646 & 4 & 30 . & 2 & 1 & $100^{\mathrm{c}}$ \\
\hline 910270 & 833 & .03 & 10 & .5 & 2 & $30^{c}$ \\
\hline 910269 & 822 & .05 & 9 & .8 & 2 & $50^{c}$ \\
\hline 910256 & 645 & .02 & 3 & .3 & 1 & $30^{c}$ \\
\hline \multicolumn{7}{|l|}{ Japan Sea } \\
\hline 910383 & 900 & .01 & 3 & .2 & 1 & $20^{c}$ \\
\hline 910393 & 1735 & na & 5 & .1 & 1 & $10^{c}$ \\
\hline
\end{tabular}

* Sedimentation rates taken from references in Table 1 , or calculated $\left({ }^{c}\right)$ from ammonia gradient, where: sed. rate $\left(\mathrm{cm} \mathrm{ka}^{-1}\right)=100$ (ammonia gradient) ${ }^{0.93}$ org. carbon ${ }^{-1}$ (Cranston, 1991a).

$\mathrm{dl}$ - below detection limit.

na - not analyzed.

of Russia, gas vents were found in two areas, with methane bubbles rising $700 \mathrm{~m}$ through the water column to the sea surface at one location. In a shallow water coastal harbour in the Gulf of St. Lawrence (Toney River, Nova Scotia), gas bubbles were escaping from the sediment and rising through 1 to $3 \mathrm{~m}$ of water to the atmosphere.

Methane was not detected in two of the study areas, one being an aquaculture site, the other Passamaquady Bay, where pockmarks on the seafloor were initially thought to be related to gas expulsion (Fader, 1991). In the case of the aquaculture site, the sediment below salmon cages were anoxic within the upper $1 \mathrm{~cm}$, and the sulfate was fully depleted by $5 \mathrm{~cm}$ downcore. Ammonia concentrations exceeded $4 \mathrm{mM}$. Hydrogen sulfide gas was detected, but methane gas was not. It is possible that because the samples were taken in January, the bottom temperature $\left(3^{\circ} \mathrm{C}\right)$ was too low to allow methanogenesis to occur. Another possibility is that antibiotics used at the site suppressed the production of methane. In Passamaquoddy Bay, a remotely operated submersible vehicle was used to study the seafloor around pockmarks and to collect cores. In all cases, the cores were fully oxidized, there was no indication of sulfate depletion or ammonia production and methane was not detected.

\section{Discussion}

\section{Diffusion of Methane from Marine Sediments}

Ammonia and sulfate gradients are plotted (Fig. 2) to show the relationship between sulfate consumption and ammonia release. A theoretical relationship, labelled S/N $=6.5$, represents the expected Redfield ratio where 6.5 units of sulfate are consumed for every unit of ammonia released (corrected for differences in apparent diffusion coefficients (Christensen et al., 1987)). The measured gradients (Table 2) tend to fall on or below the theoretical line.

It is well documented that sulfate is consumed during anaerobic methane oxidation as methane diffuses upwards into the sulfate bearing zone, even though the 
responsible bacteria has not been isolated (Alperin \& Reeburgh, 1984; Iversen \& Jørgensen, 1985; Martens et al., 1991; Reeburgh, 1992). If equal amounts of sulfate are consumed by detrital organic carbon and by methane oxidation, this would double $S / N$ to 13 , which more closely represents the observed relationship between sulfate and ammonia (Fig. 2). The three Okhotsk Sea vent area cores, where hydrates were recovered, are shown in fig. 2. In these areas, the excess of methane depleted sulfate concentrations more than was expected, based on ammonia production.

In a recent presentation, Reeburgh (1992) estimated that more than $99 \%$ of the biogenic methane diffusing upwards in the sediment column into the sulfate zone is oxidized before reaching the overlying seawater. The methane is converted to carbon dioxide which dissolves in the pore water, increasing the total alkalinity. The following summary equation can be used to describe these reactions:

$$
\mathrm{CH}_{4}+\mathrm{SO}_{4}^{-2}=\mathrm{HS}^{-}+\mathrm{HCO}_{3}^{-}+\mathrm{H}_{2} \mathrm{O}
$$

If the solubility of calcium carbonate is exceeded, carbonate precipitation occurs. Carbonate concretions near methane vents are often observed (Dando et al., 1991; Ginsburg et al., 1993; Hovland \& Judd, 1988; Jensen et al., 1992; Monastersky, 1989).

The methane oxidation potential of ocean water and sediments can be estimated from field and laboratory oxidation rates. The world ocean volume is on the order of $10^{21} \mathrm{~L}$, and the oxidation rate for methane ranges from $10^{-3}$ to $10^{1} \mathrm{nM} \mathrm{d}^{-1}$ (de Angelis, 1989; Scranton \& McShane, 1991), thus the potential oxidation rate for the world ocean is from $10^{1}$ to $10^{4} \mathrm{TgC} \mathrm{a}^{-1}$. The oxidation rate for sulfate-rich marine sediments is estimated to be on the order of 1 mmole $\mathrm{CH}_{4} \mathrm{~m}^{-2} \mathrm{~d}^{-1}$ (Alperin \& Reeburgh, 1984; Devol, 1983; Iversen \& Jørgensen, 1985). Estimating a sediment surface area for the world's oceans of $10^{8} \mathrm{~km}^{2}$, the methane oxidation potential for marine sediment is on the order of $10^{2} \mathrm{TgC}^{-1}$. Methane oxidation in the atmosphere is estimated to be about 400 $\mathrm{TgC} \mathrm{a}^{-1}$ (Cicerone \& Oremland, 1988). Based on observations at sites listed in table 1 , methane was effectively consumed in overlying sulfate-rich sediments in all cases where gas bubbles were not observed, thus supporting the conclusion that diffusive transport of methane from marine sediments to the atmosphere is minimal due to methane oxidation. The diffusional flux of oxidants into the sediment column balances the upward methane flux and effectively eliminates diffusion processes as a means of transporting methane from the sediment to the ocean and to the atmosphere. Only in special regions where sulfate is not present (e.g. under anoxic water columns; in fresh water lakes), does biogenic production allow methane to diffuse from the sediment environment (Strayer \& Tiedje, 1978). The entire sea floor can be divided into areas that have sulfate-rich layers of differing thicknesses. Using Fick's Law, diffusion of methane through the sulfate-rich zones can be estimated from the methane concentration gradient (change in concentration from the base to the top of the sulfate-rich layer), multiplied by the molecular diffusion coefficient for methane in sediments, and multiplying this flux by area and time. In all calculations, the annual release of methane diffusing from the sediment column is less than $1 \mathrm{TgC} \mathrm{a}^{-1}$. Based on the discussion above, the methane flux diffusing from marine sediments and reaching the atmosphere is estimated to be $\leq 1 \mathrm{TgC}$ $\mathbf{a}^{-1}$.

\section{Advective Transport of Methane from Marine Sediments}

If sufficient dissolved methane is available at given temperature and pressure conditions, gas bubbles may form. Wheeler (1990) concluded that bubble transport through sediments could be significant along fissues or faults in the sediment column or under storm conditions. Quantitative estimates of the amount of methane being released from sea floor vents are difficult to make. Occurrences are scattered (Hovland \& Judd, 1988), the footprint of the vent is often small and difficult to find (Ginsburg et al., 1993) and gas releases may be infrequent. Clarke \& Cleverley (1991) reviewed evidence of petroleum seeps at thousands of sites. They estimate that individual vents may release up to $10^{8} \mathrm{gC}^{-1}$, however no quantitative measurements actually have been made and the number of active sites worldwide is not know.

\section{(a) Advective Transport in Shallow Marine Areas - Toney Harbour}

Methane bubbles have been observed in areas where high organic carbon deposition rates occur in warm, shallow water (e.g. harbours, estuaries, basins, aquaculture sites, fish processing plants). Warm temperatures enhance methane production and decrease its solubility. These strongly reducing environments have thin sulfate rich layers, thus methane oxidation in the sediment is minimal. In shallow water, less methane is required to form bubbles than in deeper water. Bubbles form when dissolved methane concentrations reach $3 \mathrm{mM}$ in $1 \mathrm{~m}$ of water at $20^{\circ} \mathrm{C}$, compared to $25 \mathrm{mM}$ in water depths of $100 \mathrm{~m}$ at $5^{\circ} \mathrm{C}$. The gas bubbles travel through the shallow water to the atmosphere before dissolution or oxidation can totally consume them.

The Toney River site (Table 1) collects organic rich sediments from the river and discarded fish debris from fishing boats, resulting in high carbon loading and methane production. Bubbles rise through the 1 to $3 \mathrm{~m}$ water column during the summer and early autumn when water temperatures exceed $20^{\circ} \mathrm{C}$. The bubbles have an average diameter of $1 \mathrm{~cm}$ and are released at a rate of 1 per second per square metre of sediment (visual observation). The area affected is about $10^{4} \mathrm{~m}^{2}$, thus over a 3 month release period, on the order of $10^{7} \mathrm{gC}$ is released as methane. If similar sites occur worldwide for each kilometer of coast 
line $\left(10^{5} \mathrm{~km}\right)$, this could provide an atmospheric methane release on the order of $1 \mathrm{TgC} \mathrm{a}^{-1}$. From personal observations in a variety of coastal areas, I observe that such sites do not occur every few kilometers, thus it is concluded that methane bubbling from shallow coastal sites adds $\leq 1$ $\mathrm{TgC} \mathrm{a}^{-1}$ methane to the atmosphere.

\section{Okhotsk Sea Deep Water Methane Vents}

Gas plumes were studied in 600 to $800 \mathrm{~m}$ of water in the Okhotsk Sea at a number of locations (Ginsburg et al., 1993). The plumes, hundreds of metres high, were monitored with a $20 \mathrm{Khz}$ fish finding sounder. At one site, bubbles ( $1 \mathrm{~mm}$ radius) were observed at the sea surface, indicating that a fraction of the gas being released from the vent some $700 \mathrm{~m}$ below was reaching the atmosphere. Based on submersible studies at one of the sites, Zonenshayn et al. (1987) observed small holes in the sea floor with bubble streams releasing 1 bubble per second (1 $\mathrm{cm}$ radius) from each hole, which would allow on the order of $10^{7} \mathrm{gC} \mathrm{a}^{-1}$ per hole to escape (Cranston et al., 1993). Each vent area had at least thousands of bubble streams, thus each vent area could release on the order of $10^{10} \mathrm{gC} \mathrm{a}^{-1}$. If $90 \%$ of the venting gas is dissolved, diluted and oxidized in the water column, the atmospheric release can be estimated to be $10 \%$ of the total, or on the order of $10^{9} \mathrm{gC} \mathrm{a}^{-1}$. It appears that the Okhotsk Sea has at least on the order of 10 such vents (Cranston \& Lorenson, 1992; Ginsburg et al., 1993), which could lead to speculation that worldwide there could be 100 to 1000 vents. If 1000 vents are considered, this release mechanism could supply $1 \mathrm{TgC} \mathrm{a}^{-1}\left(10^{9} \mathrm{gC} \mathrm{a}^{-1}\right.$ vent $^{-1} \times 1000$ vents $)$ to the atmosphere.

\section{Hydrate Formation as a Reservoir of Marine Methane}

A large amount of methane is thought to be held in the marine environment in the form of methane hydrate deposits (Kvenvolden, 1988). Hydrates consist of ice-like structures containing water and significant amounts of a dissolved gas such as methane, carbon dioxide, etc. under specific temperature and pressure conditions. In the case of methane, a pure type-I methane hydrate contains 1 part methane to 8 parts water, with a density of $0.9 \mathrm{~g} / \mathrm{cc}$. At an average seafloor temperature of $3^{\circ} \mathrm{C}$, this structure would be stable at water depths in excess of $400 \mathrm{~m}$ (Sloan, 1989).

Marine hydrate deposits have been recovered from surficial sediments in the Black Sea, Okhotsk Sea, Caspian Sea, Gulf of Mexico, California coast etc., as well as from deep sediment sequences collected during the Deep Sea Drilling Program and the Ocean Drilling Program, and associated with permafrost deposits in high latitudes (Soloviev, this volume). It is necessary to quantify the marine hydrate role in the global atmospheric methane budget, since hydrate deposits may contain millions of $\mathrm{TgC}$ as methane (Kvenvolden, 1988), some of which is vulnerable to melting if ocean temperatures increases (e.g. due to global warming), if warm ocean currents change pathways, or if overlying pressure decreases (e.g. glaciers retreating, sediment slumping).

Methane hydrate samples were recovered in the Okhotsk Sea (Table 1), in $3 \mathrm{~m}$ long gravity cores collected in water depths of 700 to $800 \mathrm{~m}$ (Cranston, 1991b; Cranston, 1992; Ginsburg et al., 1993). Initial analyses show that the sediment contained 30 to $50 \%$ methane hydrate by volume. Trace amounts of ethane $(\leq 40 \mathrm{ppm})$ and propane $(\leq 20 \mathrm{ppmv})$ were present, while methane made up $>97 \%$ of the gas released when hydrate samples were melted. The hydrate appeared to form in horizontal layers in the vicinity of gas plumes. The hydrates were well within the temperature/pressure stability field, thus it was concluded that hydrates were forming (i.e. not melting) at the vent sites.

\section{Pockmarks and Gas Release Processes}

Pockmarks are circular depressions in the sea floor, often several metres deep and tens of metres in diameter, and are thought to result from active gas venting (Fader, 1991; Hovland \& Judd, 1988). Studies in the North Sea verify that gas is venting from some pockmarks (Dando et al., 1991). In 1990, a remote controlled vehicle was used to study pockmarks identified by Fader (1991) in Passamoquaddy Bay, New Brunswick, Canada (Table 1). After viewing a number of pockmarks with the in situ television system and collecting core samples with the articulated arms, we could not find any evidence of methane or of sulfate reduction, suggesting that methane had not passed through the sediment column in at least the past few hundred years, based on estimating the time required for sulfate profiles to re-establish after a methane release event. This suggests that some portion of the global pockmark population is not releasing gas. It is not known how many pockmarks exist, what fraction are actively venting methane, what amount of methane is vented from an 'average' pockmark, and what fraction reaches the atmosphere.

\section{Global warming and the marine methane cycle}

Positive feedback mechanisms due to global warming must be considered in the marine methane cycle. As the atmosphere warms, so does the upper ocean. Higher temperatures enhance the microbial production of methane and tend to increase the biogenic diffusive flux from the sediment column to the ocean. However, most of the diffusing methane is consumed by microbial oxidation, a process that also becomes more efficient as temperature increases. More research on temperature dependancy is required, but it is likely that there will be little change in the overall diffusive flux of biogenic methane from marine sediments to the atmosphere due to global warming. 
A second, more troublesome feedback mechanism which is often mentioned but poorly quantified, is that of methane hydrate melting. If significant amounts of hydrate exist in the sediment column at or near the upper limit of the temperature/pressure stability field, warmer ocean water would cause some hydrate to melt. If the upper ocean warms a few tenths of a degree Celcius over the next century, the heat will be conducted into the sediment column a few metres. Increasing the temperature $0.3^{\circ} \mathrm{C}$ will drop the stability pressure by about $10 \mathrm{~m}$ of water depth (Sloan, 1989). For a seafloor slope of $10 \%$, (e.g. along the Scotian Slope in water depths between 300 and $500 \mathrm{~m} ; 42^{\circ} 50^{\circ} \mathrm{N}, 63^{\circ} \mathrm{W}$ ) a drop of $10 \mathrm{~m}$ vertically will destabilize a zone $100 \mathrm{~m}$ wide along the seafloor. If a $10 \mathrm{~m}$ thick layer of hydrate is vulnerable (discussed above), and the layer contains pure methane hydrate, which contains $10^{5} \mathrm{gC}$ (methane) $\mathrm{m}^{-3}$ (wet sediment), estimates of methane releases over the next century can be made, depending on the total length of 'vulnerable' deposts around the continental margins of the world. If there are $1000 \mathrm{~km}$ of vulnerable deposits, $10 \mathrm{~m}$ thick, over a $100 \mathrm{~m}$ wide band, this $10^{9} \mathrm{~m}^{3}$ volume contains $10^{9} \mathrm{~m}^{3} \times 10^{5} \mathrm{~g} / \mathrm{m}^{3}=10^{14} \mathrm{gC}$, which if released over a century would be $1 \mathrm{TgC} \mathrm{a} \mathrm{a}^{-1}$. The latent heat of dissociation for hydrates would tend to slow the melting of hydrate, and the water column would disperse and oxidize some of the methane, but the key unknown factor is whether there are thousands of kilometers of 'vulnerable' hydrate along the ocean margins in this narrow band. During efforts to find such deposits along the Scotian Shelf, Grand Banks and Japan Sea margin, no 'vulnerable' hydrate deposits were encountered (Anonymous, 1991; Cranston, 1991b) suggesting that such deposits may be rare. Kvenvolden et al. (1993) provide evidience of 14 locations in the oceans of the world where hydrates have been recovered, and 33 locations where hydrates probably occur. As more studies are carried out, it is certain that more deposits will be found. Careful consideration must be made to whether any major depoists fall into the 'vulnerable' category.

The Okhotsk hydrates, under $800 \mathrm{~m}$ of water, would melt if the water temperature increased by $8^{\circ} \mathrm{C}$. This amount of warming in the ocean is not predicted, however if, for example, warm ocean currents begin to change course because of global warming, it is possible that some hydrate deposits along coastal margins could experience large temperature changes.

\section{Conclusion}

Methane release estimates from oceans and marine sediments to the atmosphere are estimated to be in the range of 1 to $10 \mathrm{TgC} \mathrm{a}^{-1}$, based on field observations and global extrapolations. These include releases from sediments via diffusive transport, from organic-rich, shallow water coastal sites as bubbling vents, from deeper marine sites (vents, pockmarks), with some consideration given to releases from gas hydrate deposits. The major problems with the vent estimates arise from the fact that the number of active sea vents in all oceans is not known, vents release different amounts, some vents are episodic, and an unknown fraction of the gas released at the seafloor actually reaches the atmosphere. Large uncertainties also arise when global warming is considered as a threat to hydrate deposits. If many thousands of kilometers of 'vulnerable' hydrate deposits actually exist along continental margins, slight warming of the ocean (due to a warmer atmosphere and/or changing ocean currents) could melt a portion of the hydrate deposits and release significant amounts of methane to the atmosphere. In order for progress to be made in estimating marine methane releases, coordinated research to study vulnerable areas world-wide is required. Quantitative flux studies at vent sites are necessary, vent and hydrate deposit locations need to be consolidated in a data base, and remote sensing techniques to identify vent sites need to be developed.

\section{Dansk sammendrag}

Methan er den mest hyppige kulbrinte i atmosphæren og er en mere effektiv drivhusgas end f.eks kuldioxid. Indholdet af methan i atmosphæren stiger for øjeblikket med ca. $0.8 \%$ pr. år. En væsentlig del af den naturlige tilførsel af methan til atmospharen kommer fra gasproducerende marine sedimenter. En række af submarine gasudslip ud for Canadas og Ruslands kyster er blevet undersøgt i detalje med henblik på en estimering af methantilskudet til atmosphæren. Mere end $99 \%$ af den i vandsøjlen diffunderende methan formodes at blive forbrugt under microbielle oxidationsprocesser. Men en brøkdel vil dog nå frem til atmosphæren, og størrelsesordenen af den frigivne methan er anslået til at ligge intervallet 1 til 10 $\mathrm{TgC} \mathrm{a}^{-1}\left(1 \mathrm{Tg}=10^{12} \mathrm{~g}\right)$. Denne estimering er baseret på observationer af kendte submarine gasudsivninger. Imidlertid er beregningen af det totale globale tilskud af methan til atmosphæren fra marine sedimenter dog behæftet med meget stor usikkerhed, da submarine gasudsivninger kun er kendt i ringe omfang. Et væsentligt usikkerhedsmoment $\mathbf{i}$ beregningsgrundlaget er ligeledes de meget store forekomster af gashydrater i kontinentalskråningernes sedimenter. En svag opvarmning af oceanerne, som følge af en varmere atmosphære eller ændrede havstrømme formodes at kunne frigive meget store mængder af methan til atmosphæren fra disse gashydrater. Det er derfor nødvendigt med en intensiveret kortlægning af de submarine gasudsivninger og udbredelsen af gashydrater for at kunne give et bedre grundlag for bedømmelsen af det stigende indhold af drivhusgassen methan $i$ atmosphæren. 


\section{References}

Alperin, M. J. and Reeburgh, W. S. 1984: Geochemical observations supporting anaerobic methane oxidation. In R.L. Crawford and R. S. Hanson (eds) Microbial Growth on C-1 Compounds Amer. Soc. for Microbiology, 282-289.

Alperin, M. J. and Reeburgh, W. S. 1985: Inhibition experiments on anaerobic methane oxidation. Applied and Environmental Microbiology 50, 940-945.

Anderson, A. L. and Bryant, W. R. 1990: Gassy sediment occurrence and properties: Northern Gulf of Mexićco. Geo-Marine Letters 10, 209-220.

Anonymous, 1991: Cruise Report Hudson 91-020. Bedford Institute of Oceanography, Dartmouth, Nova Scotia, Canada, $180 \mathrm{p}$.

Buckley, D. E. 1991: Deposition and diagenetic alteration of sediment in Emerald Basin, the Scotian Shelf. Continental Shelf Research 11, 1099-1122.

Buckley, D. E., Fitzgerald, R. A., Winters, G. V., LeBlanc, K. W. G., and Cranston, R. E. 1991: Geochemical data from analyses of sediments and pore waters obtained from cores collected in Halifax Inlet: M.V.F. Creed Cruise 90 and C.S.S. Hudson Cruise 89-039. Geological Survey of Canada Open File Report nr. 2410, 116 p.

Canfield, D. E. 1989: Sulfate reduction and oxic respiration in marine sediments: implications for organic carbon preservation in euxinic environments. Deep Sea Research 36, 121138.

Christensen, J. P., Murray, J. W., Devol, A. H. and Codispoti, L. A. 1987: Denitrification in continental shelf sediments has major impact on the oceanic nitrogen budget. Global Biogeochemical Cycles 1, 97-116.

Cicerone, R. J. and Oremland, R. S. 1988: Biogeochemical aspects of atmospheric methane. Global Biogeochemical Cycles 2, (4), 299-327.

Clarke, R. H. and Cleverly, R. W. 1991: Petroleum seepage and post-accumulation migration. In W.A. England and A.J. Fleet (eds) Petroleum Migration, Geological Society, Special Publication no. 59, 265-271, London.

Cranston, R. E. 1991a: Sedimentation rate estimates from sulfate and ammonia gradients. Proc. ODP, Sci. Results 119, College Station, Tx (Ocean Drilling Program), 401-405.

Cranston, R. E. 1991b: Gas Hydrate Investigations in the Okhotsk/Japan Seas. Geological Survey of Canada Open File Report nr. 2446, 100 p.

Cranston, R. E., Ginsburg, G. D., Soloviev, V. A. and Lorenson, T. D. 1993: Gas venting and hydrate deposits in the Okhotsk Sea. Bulletin of the Geological Society of Denmark (elsewhere in this volume).

Cranston, R. E. and Lorenson, T. D. 1992: Recent discovery of a methane hydrate reservoir off the east coast of Russia: implications for global methane budgets. NIGEC Atmospheric Methane Conference, Jan. 1992. National Institute for Global Environmental Change, F. S. Rowland, Department of Chemistry, UC Irvine, Irvine, CA 92717.

Cranston, R. E. and Standing, P. D. 1992: Geochemical and sedimentological results from sediment cores collected in the Okhotsk/Japan Seas. Geological Survey of Canada Open File Report nr. 2520, 66 p.

Cynar, R. J. and Yayanos, A. A. 1992: Processes controlling the distribution of methane in the California Current system. NIGEC Atmospheric Methane Conference, Jan. 1992. National Institute for Global Environmental Change, F. S. Rowland, Department of Chemistry, UC Irvine, Irvine, CA 92717.

Dando, P. R., Austen, M. C., Burke, R. A. Jr., Kendall, M. A., Kennicutt II, M. C., Judd, A. G., Moore, D. C., O'Hara, S. C. M., Schmaljohann, R., Southward, A. J. 1991: Ecology of a North Sea pockmark with an active methane seep. Mar. Ecol. Prog. Ser. 70, 49-63.

de Angelis, M. A. 1989: Studies of microbial methane oxidation in deep sea hydrothermal vent environments. University of Washington dissertation, $160 \mathrm{p}$.
Devol, A. H. 1983: Methane oxidation rates in the anaerobic sediments of Saanich Inlet. Limnol. Oceanogr. 28, (4), 738742.

Fader, G. B. J. 1991: Gas-related sedimentary features from the eastern Canadian continental shelf. Continental Shelf Research 11, 1123-1153.

Fitzgerald, R. A., Winters, G. V., LeBlanc, K. W. G., Buckley, D. E. and Cranston, R. E. 1991: Geochemical data from analyses of sediments and pore waters obtained from cores collected in Halifax Inlet: C.S.S. Navicula Cruise 90-010. Geological Survey of Canada Open File Report nr. 2449, 106 p.

Ginsburg, G. D., Soloviev, V. A., Cranston, R. E., Lorenson, T. D. and Kvenvolden, K. A. 1993: Gas hydrates from the continental slope, offshore Sakhalin Island, Okhotsk Sea. Geo-Marine Letters 13, 41-48.

Henrichs, S. M. and Reeburgh, W. S. 1987: Anaerobic mineralization of marine sediment organic matter: rates and the role of anaerobic processes in the oceanic carbon economy. Geomicrobiology Journal 5, 191-237.

Houghton, J. T., Jenkins, G. J. and Ephraums, J. J. 1990: Climate Change - The IPCC Scientific Assessment. Cambridge University Press, Cambridge, U.K. 365 p.

Hovland, M. and Judd, A. G. 1988: Seabed pockmarks and seepages, Graham and Trotman Inc. Sterling House, London $293 \mathrm{p}$.

Iversen, N. and Jørgensen, B. B. 1985: Anaerobic methane oxidation rates at the sulfate-methane transition in marine sediments from Kattegat and Skagerrak (Denmark). Limnol. Oceanogr. 30, (5), 944-955.

Jensen, P., Aagaard, I., Burke Jr., R. A., Dando, P. R. Jørgensen, N. O., Kuijpers, A., Laier, T., O'Hara, S. C. M. and SchmalJohann, R. 1992: 'Bubbling reefs' in the Kattegut: submarine landscapes of carbonate-cemented rocks support a diverse ecosystem at methane seeps. Marine Ecology Progress Series $83,103-112$

Kvenvolden, K. A. 1988: Methane hydrates and global climate. Global Biogeochemical Cycles 2, 221-229.

Kvenvolden, K. A., Ginsburg, G. D. and Soloviev, V. A. 1993: Worldwide distribution of subaquatic gas hydrates. Geo-Marine Letters 13, 32-40.

Lambert, G. and Schmidt, S. 1992: Re-evaluation of the oceanic flux of methane. NIGEC Atmospheric Methane Conference, Jan. 1992. National Institute for Global Environmental Change, F. S. Rowland, Department of Chemistry, UC Irvine, Irvine, CA 92717.

LeBlanc, K. W. G., Fitzgerald, R. A., Winters, G. V., Buckley, D. E. and Cranston, R. E. 1991: Geochemical data from analyses of sediments and pore waters obtained from cores collected in Halifax Inlet. Geological Survey of Canada Open File Report nr. 2345, $116 \mathrm{p}$.

MacDonald, G. J. 1983: The many origins of natural gas. J. Petrol. Geology 5, 341-362.

Martens, C. S., Chanton, J. P. and Paull, C. K. 1991: Biogenic methane from abyssal brine seeps at the base of the Florida escarpment. Geology 19, 851-854.

Martens, C. S. and Val Klump, J. 1984: Biogeochemical cycling in an organic-rich coastal marine basin 4 . An organic carbon budget for sediments dominated by sulfate reduction and methanogenesis. Geochim. Cosmochim. Acta 48, 1987-2004.

Matson, M. 1986: Large plume events in the Soviet Arctic. EOS 27, 1372-1373.

Miller, J. J, Myung, W. L. and von Huene, R. 1991: An analysis of a seismic reflection from the base of a gas hydrate zone, offshore Peru. Amer. Assoc.Petrol. Geologists Bulletin 75, (5), 910-924.

Monastersky, R. 1989: Methane key to Arctic mystery mounds. Science 243, 215.

Nisbet, E. G. 1989: Some northern sources of atmospheric methane: production, history, and future implications. Can. J. Earth Science 26, 1603-1611.

Reeburgh, W. S., 1992: Methane oxidation in soils and water. 
NIGEC Atmospheric Methane Conference, Jan. 1992. National Institute for Global Environmental Change, F.S. Rowland, Department of Chemistry, UC Irvine, Irvine, CA 92717.

Schoell, M. 1988: Multiple origins of methane in the earth. Chemical Geology 71, 1-10.

Scranton, M.I. and McShane, 1991: Methane fluxes in the Southern North Sea: the role of European rivers. Continental Shelf Research 11, 37-52.

Sloan Jr., E. D. 1989: Clathrate hydrates of natural gases. Marcel Dekker Inc. New York, $641 \mathrm{p}$

Solorzano, L., 1969: Determination of ammonia in nautral waters by phenolhypochlorite method. Limnol. Oceanogr. 14, 799-801.

Strayer, R. F. and Tiedje, J. M., 1978: In situ methane production in a small, hypereutorphic, hardwater lake: Loss of methane from sediments by vertical diffusion and ebullition. Limnology and Oceanography 23, 1201-1206.
Welham, J. and Craig, H., 1979: Methane and hydrogen in East Pacific Rise hydrothermal fluids. Geophys. Res. Letters 5, 829-831.

Wheeler, S.J. 1990: Movement of large gas bubbles in unsaturated fine-grained sediments. Marine Geotechnology 9, $113-129$

Whiticar, M. J., Faber, E. and Schoell, M. 1986: Biogenic methane formation in marine and freshwater environments: $\mathrm{CO}_{2}$ reduction vs. acetate fermentation - Isotope evidence. Geochimica et Cosmochimica Acta 50, 693-709.

Zonenshayn, L. P., Murdmaa, I. O., Baranov, B. V., Kuznetsov, A. P., Kuzin, V. S., Kuz'min, M. I., Avdeiko, G. P., Stunzhas, P. A., Lukashin, V. N., Barash, M. S., Valyasho, G. M. and Dyomina, L. L. 1987: Underwater gas source: Sea of Okhotsk. Oceanology 27, 598-602. 